\title{
Characterization of copy numbers of I6S rDNA and I6S rRNA of Candidatus Liberibacter asiaticus and the implication in detection in planta using quantitative PCR Jeong-soon $\mathrm{Kim}^{1}$ and Nian Wang*1,2
}

Address: ${ }^{1}$ Citrus Research and Education Center, University of Florida, 700 Experiment Station Road, Lake Alfred, FL 33850, USA and ${ }^{2}$ Department of Microbiology and Cell Science, University of Florida, Gainesville, FL 32611, USA

Email: Jeong-soon Kim - jeongsoonkim@ufl.edu; Nian Wang* - nianwang@ufl.edu

* Corresponding author

Published: 6 March 2009

BMC Research Notes 2009, 2:37 doi:10.1/86/1756-0500-2-37
Received: 8 October 2008

Accepted: 6 March 2009

This article is available from: http://www.biomedcentral.com/I756-0500/2/37

(c) 2009 Wang et al; licensee BioMed Central Ltd.

This is an Open Access article distributed under the terms of the Creative Commons Attribution License (http://creativecommons.org/licenses/by/2.0), which permits unrestricted use, distribution, and reproduction in any medium, provided the original work is properly cited.

\begin{abstract}
Background: Citrus Huanglongbing (HLB) is one of the most devastating diseases on citrus and is associated with Candidatus Liberibacter spp.. The pathogens are phloem limited and have not been cultured in vitro. The current management strategy of HLB is to remove infected citrus trees and reduce psyllid populations with insecticides to prevent the spreading. This strategy requires sensitive and reliable diagnostic methods for early detection.
\end{abstract}

Results: We investigated the copy numbers of the I6S rDNA and I6S rRNA of the HLB pathogen and the implication of improving the diagnosis of HLB for early detection using Quantitative PCR. We compared the detection of HLB with different Quantitative PCR based methods with primers/ probe targeting either I6S rDNA, beta-operon DNA, I6S rRNA, or beta-operon RNA. The I6S rDNA copy number of $C a$. Liberibacter asiaticus was estimated to be three times of that of the beta-operon region, thus allowing detection of lower titer of $\mathrm{Ca}$. L. asiaticus. Quantitative reverse transcriptional PCR (QRT-PCR) indicated that the $16 \mathrm{~S}$ rRNA averaged 7.83 times more than that of I6S rDNA for the same samples. Dilution analysis also indicates that QRT-PCR targeting I6S rRNA is 10 time more sensitive than QPCR targeting $16 \mathrm{~S}$ rDNA. Thus QRT-PCR was able to increase the sensitivity of detection by targeting $16 \mathrm{~S}$ rRNA.

Conclusion: Our result indicates that Candidatus Liberibacter asiaticus contains three copies of $16 \mathrm{~S}$ rDNA. The copy number of $16 \mathrm{~S}$ rRNA of $\mathrm{Ca}$. L. asiaticus in planta averaged about 7.8 times of I6S rDNA for the same set of samples tested in this study. Detection sensitivity of HLB could be improved through the following approaches: using $16 \mathrm{~S}$ rDNA based primers/probe in the QPCR assays; and using QRT-PCR assays targeting I6S rRNA.

\section{Background}

Citrus Huanglongbing (HLB) is one of the most devastating diseases on citrus and is associated with a phloem limited bacterium which has yet to be cultured in vitro. Consequently, the pathogen was given a provisional Can- didatus status in nomenclature $[1,2]$. Currently, three species of the pathogen are recognized from trees with HLB disease based on 16S rDNA sequence: Candidatus Liberibacter asiaticus (Las), Ca. Liberibacter africanus (Laf), and $\mathrm{Ca}$. Liberibacter americanus (Lam); Las is the most preva- 
lent species among HLB infected trees [1,3-5]. Las has been spreading worldwide over the last century and has been identified in Japan, China, Southeast Asia, India, Arabian Peninsula, Brazil, Florida and other citrus producing areas $[3,4]$. The current management strategy of HLB is to remove infected citrus trees and reduce psyllid populations with insecticides to prevent it from spreading. This strategy requires sensitive and reliable diagnostic methods for early detection.

The conventional way of diagnosing HLB is based on visual assessment of symptoms. Typical symptoms of HLB of infected trees include blotchy mottle and/or variegated chlorosis of leaves, pale yellow leaves, and stunting. The leaves become upright, followed by leaf drop from the laminar or petiole abscission zones, and at later stages extensive twig dieback occurs [3]. Often small-sized, lopsided, and bitter tasting fruits with aborted seeds are found on HLB-affected trees. However, these symptoms seem not to be HLB specific since a Phytoplasma sp. was reported to cause very similar symptoms in citrus in Brazil [6]. It is also reported that Las can survive for years in citrus before showing obvious symptoms. HLB symptoms also vary with environment and infected trees become less symptomatic under high temperature during the summer.

To overcome the shortcomings of symptom-based diagnosis, various detection methods have been developed in recent years. DNA probes, conventional and Quantitative PCR assays, electron microscope, enzyme-linked immunosorbent assays (ELISA) and biological indexing have been reported to be used for successful diagnosis $[3,7,8]$. In recent years, diagnosis of HLB based on PCR methodology (Conventional PCR and Quantitative PCR) has gained popularity due to its sensitivity and reliability $[7,8]$. In this study, we investigated the copy numbers of the 16S rDNA and 16S rRNA of Las and the implication of improving the diagnosis of HLB for early detection using either QPCR or QRT-PCR.

\section{Methods \\ Plant materials and extraction of DNA and RNA}

Citrus leaf samples were collected from the HLB symptomatic and asymptomatic sweet orange (Citrus sinensis) trees (about 5-year-old) from one citrus grove which has been confirmed to be infected with $\mathrm{Ca}$. Liberibacter asiaticus previously in Polk County, Florida, USA. Only leaves with typical blotchy mottle symptoms were used for symptomatic samples. The leaves were washed in tap water and surface sterilized in 35\% bleach ( $2 \%$ active $\left.\mathrm{Cl}^{-}\right)$ and $70 \%(\mathrm{v} / \mathrm{v})$ ethanol for $2 \mathrm{~min}$ each and rinsed three times with sterile water. Midribs were separated from leaf samples and cut into pieces. $0.1 \mathrm{~g}$ of tissue (fresh weight) from each sample was frozen in liquid nitrogen for DNA and RNA extraction, respectively. Midribs were chosen since they are phloem rich as Las is known to be phloem limited. DNA from plant samples was extracted using the Wizard $^{\circledast}$ Genomic DNA purification kit (Promega, Madison, WI, USA) following the protocol for isolating genomic DNA from plant tissue and dissolved in $100 \mu \mathrm{l}$ of water. RNA was extracted using the RNeasy mini kit (Qiagen, Valencia, CA, USA) following the manufacturers' instructions and dissolved in $100 \mu$ l of water.

\section{Quantitative PCR (QPCR)}

All QPCR assays were performed using ABI PRISM 7500 Sequence detection system (Applied Biosystems, Foster City, CA, USA). The Primer/probe set, CQULA04FCQULAP10-CQULA04R, was used to target the $\beta$-operon region of Las. For $16 \mathrm{~S}$ rDNA, QPCR was carried out with the primers and probe HLBas/HLBr/HLBp for Las essentially as described in Li et al. [7]. Both primer/probe sets have been successfully used for diagnosis and detection. The specificity of primer/probe CQULA04F-CQULAP10CQULA04R and HLBas/HLBr/HLBp has been confirmed previously $[7,8]$. The probes were labelled with 56-FAM as a reporter fluorescent dye at the 5 ' end and with 3BHQ_1 as the quencher dye. QPCR reactions were performed according to the condition described previously with modification [8]. Briefly, QPCR reactions were performed in a $25 \mu \mathrm{L}$ reaction using $2 \times$ Quantitect Probe PCR master mix (Qiagen, Valencia, CA, USA), $0.8 \mu \mathrm{M}$ of each primer, $0.4 \mu \mathrm{M}$ of probe (IDT, Coralville, IA, USA), and an appropriate amount of template DNA. The PCR conditions were $50^{\circ} \mathrm{C}$ for $2 \mathrm{~min}, 95^{\circ} \mathrm{C}$ for $15 \mathrm{~min}, 45$ cycles of each $94^{\circ} \mathrm{C}$ for $15 \mathrm{sec}$ and $60^{\circ} \mathrm{C}$ for $1 \mathrm{~min}$. Each individual QPCR assay had at least 3 replications. Results were analyzed using ABI Prism software. Raw data were analyzed using the default settings (threshold $=0.2$ ) of the software. DNA samples extracted from healthy citrus were used as negative control.

\section{Quantitative Reverse Transcriptional PCR (QRT-PCR)}

QRT-PCR was used to detect Las 16S rRNA or beta-operon RNA using the QuantiTect Probe RT-PCR Kit (Qiagen) following the manufacturer's instructions. The same primer/ probe HLBas/HLBr/HLBp and CQULA04F-CQULAP10CQULA04R for QPCR targeting 16S rDNA and $\beta$-operon region were used for QRT-PCR assays, respectively [7]. Reverse transcription was conducted at $50^{\circ} \mathrm{C}$ for $30 \mathrm{~min}$ with $1 \mu$ l of total RNA as template, then followed by initial activation of HotStarTaq DNA Polymerase $\left(95^{\circ} \mathrm{C}, 15\right.$ min). Totally, 45 cycles of reactions $\left(94^{\circ} \mathrm{C}\right.$ for $15 \mathrm{sec}$, $60^{\circ} \mathrm{C}$ for $60 \mathrm{sec}$ ) were performed. Eight samples were used for QRT-PCR assays and each individual QRT-PCR assay had 3 technical repeats. For dilution study, head to head study was conducted for DNA and RNA extracted from the same set of samples. Both DNA and RNA were diluted from 10 to $10^{7}$ times and $1 \mu$ l of DNA or RNA was used for each QPCR or QRT-PCR assay, respectively. 


\section{Results and discussion Comparing the gene copy number of I 6S rDNA and beta- operon}

Among the bacterial species, the 16S rDNA copy number varies considerably from 1 to $15[9,10]$. Thus, it is possible to target the high copy number gene for better sensitivity. QPCR has been shown to be able to determine the rDNA copy [11]. In this study, the standard equations, $\mathrm{y}=$ $0.3101 x+12.09$ and $y=-0.288 x+11.61$, which were modified from the equations previously developed for $16 \mathrm{~S}$ rDNA and beta-operon of Las respectively, to fit the conditions used in this study, were used to quantify the Las bacterial population as genome equivalents $[7,8,12]$. Totally, eight samples were used for calculation. For the same set of samples, the Las population based on the 16S rDNA method averaged $3.15 \pm 0.11$ (SD) of that calculated by beta-operon method. Thus it is estimated that the copy number of $16 \mathrm{~S}$ rDNA is three times of beta-operon. Examination of all sequenced bacteria indicated that betaoperon is one copy in bacteria. If this is also true for $\mathrm{Ca}$. Liberibacter species, the copy number for Las 165 rDNA should be three copies. By the time this manuscript was accepted, it is also learned that $\mathrm{Ca}$. Liberibacter americanus contains three copies of $16 \mathrm{~S}$ rDNA [N. Wulff pers. comm.]. The draft genome sequence of $\mathrm{Ca}$. Liberibacter asiaticus is also in accordance with our result [Y.P. Duan pers. comm.]. Thus compared to QPCR assays targeting beta-operon, a 16S rDNA based QPCR assay is likely to be more sensitive due to its higher copy number per genome.

\section{Quantitative Reverse Transcriptional PCR (QRT-PCR) targeting I6S rRNA}

It has been reported that $16 \mathrm{~s}$ rRNA could reach up to $10^{4}$ $10^{5}$ copies per cell [13]. Thus, $16 \mathrm{~S}$ rRNA should be a good target to increase the sensitivity of detection. To calculate the copy numbers of $16 \mathrm{~S}$ rDNA and $16 \mathrm{~S}$ rRNA, leaf samples from known HLB pathogen infected trees and healthy trees were aliquoted equally for DNA and RNA extraction and dissolved into $100 \mu \mathrm{l}$ water, respectively. $1 \mu \mathrm{l}$ of DNA or RNA samples from a total volume of $100 \mu$ l were used for either QRT-PCR or QPCR assays, respectively. The same equation was used to calculate the $16 \mathrm{~S}$ rRNA and $16 \mathrm{~S}$ rDNA copy number since the same sets of primer/ probe HLBas/HLBr/HLBp were used for both QRT-PCR and QPCR assays. The $16 \mathrm{~S}$ rRNA copy number is $7.83 \pm$ 4.12 (SD) times of that of $16 \mathrm{~S}$ rDNA for the same samples (Table 1). Similarly, the same equation was used to quantify the DNA and RNA copy numbers of beta-operon region. Dilution analysis of the QRT-PCR targeting 16S rRNA indicates that the RNA sample tested could be detected up to $10^{5}$ dilution (Table 2 ). However, QPCR targeting $16 \mathrm{~S}$ rDNA could detect the Las up to $10^{4}$ dilution for the same set of samples. The dilution analysis for both assays fitted the exponential relationship between $\mathrm{Ct}$ value and dilution. Inconsistent results were obtained for
Table I: Comparison of copy numbers of I6S rDNA, betaoperon DNA, I6S rRNA, and beta-operon RNA

\begin{tabular}{lll}
\hline Copy number & Average & SD \\
\hline beta-operon DNA & 130316.70 & 17022.84 \\
I6S DNA & 410145.75 & 51623.13 \\
beta-operon RNA & 1517.15 & 972.17 \\
I6S RNA & 3211824.58 & 1899947.61 \\
I6S DNA/beta-operon DNA & 3.15 & 0.11 \\
I6S RNA/I6S DNA & 7.83 & 4.12 \\
beta-operon DNA/beta-operon RNA & 85.90 & 71.93 \\
\hline
\end{tabular}

Each citrus sample was divided into two Eppendorf tubes with $0.1 \mathrm{~g}$ each for DNA or RNA extraction and dissolved into $100 \mu \mathrm{l}$ of water, respectively. I $\mu \mathrm{l}$ of DNA or RNA samples was used in either QPCR or QRT-PCR assays respectively. Totally, eight samples were used for calculation.

further dilution in both assays, thus were considered negative. This result suggests that QRT-PCR assay targeting $16 \mathrm{~S}$ rRNA is about ten times more sensitive than QPCR assay targeting $16 \mathrm{~S}$ rDNA. This data is in accordance with the fact that the $16 \mathrm{~S}$ rRNA copy number is $7.83 \pm 4.12$ (SD) times of that of $16 \mathrm{~S}$ rDNA for the same set of samples tested in this study. However, it is surprising that the $16 \mathrm{~S}$ rRNA is only 7.83 times of that of $16 \mathrm{~S}$ rDNA as $16 \mathrm{~s}$ rRNA has been reported to reach up to $10^{4}-10^{5}$ copies per cell [13]. This is probably due to the slow growth of $\mathrm{Ca}$. Liberibacter asiaticus in planta [14]. Past studies indicate that bacterial growth rate is highly correlated to various measures of RNA content [15]. This is consistent with the difficulty of detecting $\mathrm{Ca}$. Liberibacter asiaticus using Fluorescent in situ hybridization targeting 16S rRNA [N. Wang unpublished]. The high ratio of dead cells/live cell contributes to the unexpected low 16rRNA copy number. Our previous study indicated that viable Las cell rate ranging from $17 \%$ to $31 \%$ in different citrus samples using

Table 2: Comparison of QRT-PCR and QPCR assays

\begin{tabular}{lllll}
\hline Dilution & Ct value & SD & Ct value change & SD \\
\hline QPCR & & & & \\
10 & 23.87 & 0.02 & & \\
$10^{2}$ & 27.16 & 0.17 & 3.29 & 0.17 \\
$10^{3}$ & 30.47 & 0.31 & 3.30 & 0.48 \\
$10^{4}$ & 33.93 & 0.20 & 3.46 & 0.11 \\
QRT-PCR & & & & \\
10 & 20.60 & 0.01 & & 0.08 \\
$10^{2}$ & 23.77 & 0.08 & 3.17 & 0.18 \\
$10^{3}$ & 26.82 & 0.14 & 3.06 & 0.12 \\
$10^{4}$ & 29.53 & 0.12 & 2.70 & 0.80 \\
$10^{5}$ & 32.99 & 0.76 & 3.47 & \\
\hline
\end{tabular}

Each citrus sample was divided into two Eppendorf tubes with $0.1 \mathrm{~g}$ each for DNA or RNA extraction and dissolved into $100 \mu \mathrm{l}$ of water, respectively. I $\mu$ l of DNA or RNA samples was used in either QPCR or QRT-PCR assays respectively. Each value is the mean of three replicates. 
QPCR with the aid of ethidium monoazide which can differentiate viable cells from dead cells [13,16-18]. The lower copy number of the beta-operon RNA than the betaoperon DNA also suggests the majority of Las cells in planta are dead cells, which consequently contributes to the unexpected low rRNA/rDNA ratio. It is also possible that beta-operon RNA is not stable RNAs (which mainly contain rRNA and tRNA), and subjects to massive loss due to degradation in the sample preparation. Still, QRT-PCR assay targeting $16 \mathrm{~S}$ rRNA is 10 times more sensitive than QPCR. The challenge for QRT-PCR is handling RNA since it is more sensitive to degradation while DNA is quite stable. Plus, QRT-PCR assay is more expensive and more time-consuming than QPCR assay. Thus, optimization is needed to address those issues in order to make QRT-PCR practical in diagnosis.

Our previous study indicated that a minimum bacterial concentration was required for HLB symptom development in studying the population of Las in symptomatic and asymptomatic leaves [14]. Thus improvement of detection sensitivity of Las could lead to early detection of HLB without relying on symptoms on citrus.

\section{Conclusion}

Our result indicates that Las contains three copies of $16 \mathrm{~S}$ rDNA. The copy number of $16 \mathrm{~S}$ rRNA of Las in planta averaged about 7.8 times of $16 \mathrm{~S}$ rDNA. QRT-PCR targeting 16S rRNA was 10 times more sensitive than QPCR targeting $16 \mathrm{~S}$ rDNA. Detection sensitivity of HLB could be improved through the following approaches: using 16S rDNA based primers/probe in the QPCR assays; and using QRT-PCR assays targeting 16S rRNA.

\section{Competing interests}

The authors declare that they have no competing interests.

\section{Authors' contributions}

J-sK and NW conducted the experiments. NW wrote the manuscript. All authors read and approved the final manuscript.

\section{Acknowledgements}

This work has been supported by Florida Citrus Production Research Advisory Council (FCPRAC).

\section{References}

I. Jagoueix S, Bové JM, Garnier M: The phloem-limited bacterium of greening disease of citrus is a member of alpha subdivision of the Proteobacteria. Int J Syst Bacteriol 1994, 44:379-386.

2. Murray RGE, Schleifer KH: Taxonomic notes: a proposal for recording the properties of putative taxa of procaryotes. Int J Syst Bacteriol 1994, 44:174-176.

3. Bové JM: Huanglongbing: a destructive, newly-emerging, century-old disease of citrus. J Plant Pathol 2006, 88:7-37.

4. da Graça JV: Citrus greening disease. Ann Rev Phytopathol 199I, 29:109-136.

5. Teixeira DC, Ayres J, Danet JL, Jagoueix-Eveillard S, Saillard C, Bové JM: First report of a huanglongbing-like disease of citrus in
São Paulo, Brazil, and association of a new Liberibacter species, "Candidatus Liberibacter americanus" with the disease. Plant Dis 2005, 89:107.

6. Teixeira DC, Wulff NA, Martins EC, Kitajima EW, Bassanezi R, Ayres AJ, Eveillard S, Saillard C, Bové JM: A phytoplasma closely related to the Pigeon Pea Witches'-Broom Phytoplasma (I6Sr IX) is associated with citrus huanglongbing symptoms in the state of São Paulo, Brazil. Phytopathology 2008, 98:977-984.

7. Li W, Hartung JS, Levy L: Quantitative real-time PCR for detection and identification of Candidatus Liberibacter species associated with citrus huanglongbing. J Microbiol Meth 2006, 66: $104-115$

8. Wang Z, Yin Y, Hu H, Yuan Q, Peng G, Xia Y: Development and application of molecular-based diagnosis for 'Candidatus Liberibacter asiaticus', the causal pathogen of citrus huanglongbing. Plant Pathol 2006, 55:630-8.

9. Klappenbach JA, Dunbar JM, Schmidt TS: rRNA operon copy number reflects ecological strategies of bacteria. Appl Environ Microbiol 2000, 66: I 328-I333.

10. Charles H, Ishikawa H: Physical and genetic map of the genome of Buchnera, the primary endosymbiont of the pea aphid Acyrthosiphon pisun. J Mol Evol 1999, 48: I42-150.

II. Lee C, Kim J, Shin SG, Hwang S: Absolute and relative QPCR quantification of plasmid copy number in Escherichia coli. J Biotechnol 2006, I 23:273-280.

12. Tatineni S, Sagaram US, Gowda S, Robertson CJ, Dawson WO, Iwanami T, Wang N: In plant distribution of 'Candidatus Liberibacter asiaticus' as revealed by polymerase chain reaction (PCR) and real-time PCR. Phytopathology 2008, 98:592-599.

13. Zwirglmaier K, Ludwig W, Schleifer $\mathrm{KH}$ : Recognition of individual genes in a single bacterial cell by fluorescence in situ hybridization - RING-FISH. Mol Microbiol 2004, 5 I :89-96.

14. Trividi P, Sagaram US, Brlansky RH, Rogers M, Stelinski LL, Oswalt C, Kim JS, Wang N: Quantification of viable Candidatus Liberibacter asiaticus in hosts using Quantitative PCR with the aid of ethidium monoazide (EMA). Eur J Plant Path 2009.

15. Kemp PF, Lee S, LaRoche J: Estimation of the growth rate of slowly growing marine bacteria from RNA content. Appl Environ Microbiol 1993, 59:2594-2601.

16. Nocker A, Camper AK: Selective removal of DNA from dead cells of mixed bacterial communities by use of ethidium monoazide. Appl Environ Microbiol 2006, 72:1997-2004.

17. Rudi K, Moen B, Drømtrop SM, Holck AL: Use of ethidium monoazide and PCR in combination for quantification of viable and dead cells in complex samples. Appl Environ Microbiol 2005, 71: 1018-1024.

18. Wang S, Levin RE: Discrimination of viable Vibrio vulnificus cells from dead cells in real-time PCR. J Microbiol Methods 2006, 64: $1-8$.

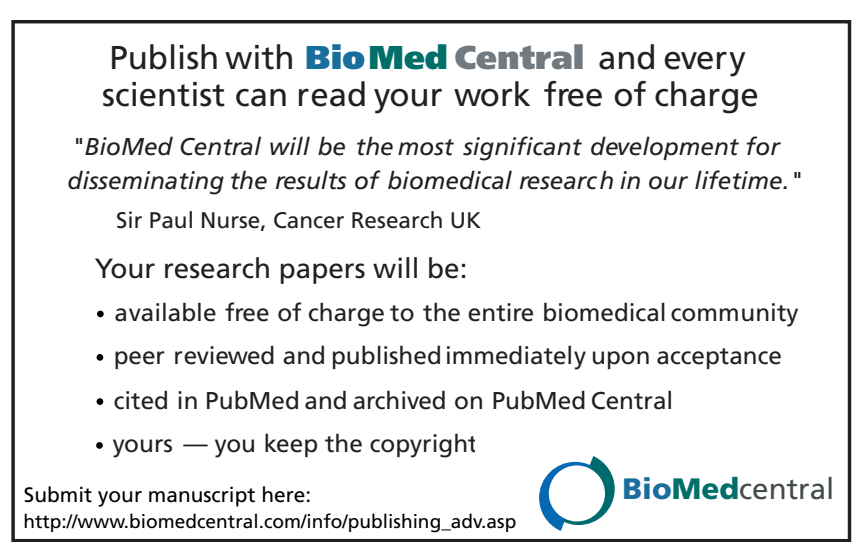

